\title{
O espectador e a contemporaneidade: perspectivas pedagógicas
}

\author{
Flávio Desgranges
}

\section{As alterações no modo de vida contemporâneo}

$\int$ esde o surgimento do teatro moderno, na virada do século XIX para o XX, até os dias atuais, a relação do espectador com a obra teatral vem sofrendo modificações significativas, e isto porque a vida moderna - e a própria maneira de representá-la - é bastante mutável. O teatro busca, assim, rever continuamente suas propostas para manter um diálogo profícuo com a sociedade.

As transformações na vida social contemporânea podem ser percebidas, em um de seus aspectos, a partir da infinidade de novos procedimentos espetaculares que imprimem um tom ficcional ao dia-a-dia e nos deixam expostos a um turbilhão de informações que se renovam a cada instante. A expansão dos meios de comunicação de massa, que ampliam incessantemente a sua capilaridade no tecido social, incrementada pela multiplicação de máquinas e eventos, e a criação constante de diferentes canais de aproximação suscitam no indivíduo contemporâneo sensações e estímulos diversos, provocam e interrompem raciocínios e estabelecem profundas alterações nos valores éticos e nos conceitos estéticos. A complexidade das redes de comunicação engendradas no século XX requi- sita, assim, maneiras próprias de perceber e compreender os acontecimentos sociais.

Outro aspecto importante das recentes modificações sociais está na falta de crédito nos projetos globais de reestruturação da vida humana, motivada pela sensação de falência dos mesmos, o que provoca a desconfiança acerca de qualquer proposição de novos projetos, ou mesmo de retomada dos antigos. E como as reformas coletivas se situam num impasse, voltase para o âmbito individual, para as descobertas de experiências e transformações pessoais. "Os atores deixam de ser sociais e voltam-se para si mesmos, para a busca narcisista da sua identidade". (Tourraine, 1997, p. 198)

As alterações do modo de vida na contemporaneidade podem ser também compreendidas a partir da análise da complexidade que atingiu o sistema capitalista mundial, diante do qual nos vemos embaraçados pela dificuldade de compreender na totalidade a sua forma. As transformações que evidenciam o advento da sociedade pós-industrial constituem sinais culturais marcantes de um novo estágio na história do modo de produção, que podem ser observados nos seguintes fenômenos atuais: a explosão tecnológica que, com seus inventos e serviços, desempenha o papel de principal fonte de lucro empresarial; o predomínio global das

Flávio Desgranges é professor do Departamento de Artes Cênicas da ECA - USP e encenador. 
corporaçôes multinacionais, diminuindo o poder de decisão dos Estados nacionais; e a ascensão e o amplo domínio dos conglomerados de comunicação, que ultrapassam as fronteiras. Fenômenos que provocaram profundas conseqüências pelos quatro cantos do planeta, alterando os interesses políticos nacionais e internacionais, o ciclo dos negócios, os padrões de emprego e até mesmo as relações de classe.

Este multifacetado modo de vida contemporâneo, composto por ingredientes bastante específicos, marca, assim, profundas alterações nas relações econômicas, políticas e sociais, se comparadas àquelas engendradas na modernidade, e requisita novos procedimentos estéticos que possam estabelecer um diálogo efetivo com os espectadores deste tempo.

"O fato é que a sensibilidade atual é claramente distinta da que vigorou até o início da Segunda Guerra Mundial ou, para procurar outros marcos, diversa da que orientou a percepção, a emoção e a reflexão até o advento da bomba atômica, o desenvolvimento da televisão e a formulação do novo pensamento científico que, iniciado com Einstein na primeira metade do século, foi (e vai) lentamente penetrando o cotidiano. Depois de Hiroshima e Nagasaki, da Guerra Fria, da invasão da Hungria pela URSS, da Guerra do Vietnã, da rebelião dos jovens em 1968, da Primavera de Praga, do choque do petróleo, da queda do muro de Berlim, do esfacelamento da antiga URSS e da inquietante ascensão dos pré-modernos fundamentalismos religiosos em todos os seus modos e versōes, a sensibilidade humana não pode mais ser a mesma e não pode mais ser estimulada ou atingida pelas propostas que, de um modo ou de outro, puderam ser chamadas de modernas." (Teixeira Coelho, 1995, p. 7)

Pode-se observar, a partir das últimas décadas do século XX, um esmaecimento da perspectiva revolucionária da modernidade, não apenas em suas inovações artísticas, mas no questionamento aos seus principais valores constitutivos, que são: a aposta na existência de uma razão universal capaz de definir com segurança os rumos da coletividade, a valorização da idéia de pátria e a busca pelo incessante progresso da humanidade. Um conjunto de valores que se revelam desgastados, o que indica a busca de novas direções, já que o investimento nestes valores não significou nem de longe, e a história o demonstra, a prometida conquista da felicidade pelos homens.

Define-se a dita "falência" dos projetos iluministas, em especial o liberalismo e o socialismo, que alimentaram a utopia da modernidade - apoiados na idéia gerada no Iluminismo de uma razão libertadora, voltada para a concretização dos anseios de justiça social e de autonomia do homem -, a partir do momento em que se percebe que a universalidade da razão pode não ser um parâmetro eficaz para qualquer grande projeto de transformação, tomando-se como exemplo os atos de barbárie desencadeados em nossa história recente em nome da razão.

A arte moderna estava, de uma ou outra maneira, vinculada a este projeto revolucionário de transformação da vida social, inspirada pela visão utópica de um novo mundo possível. Atualmente, este novo mundo parece inconcebível ou, ao menos, não se conseguem formular opções consensuais sobre que caminhos trilhar para alcançá-lo. Assim, uma proposição estética ancorada em qualquer síntese coletiva, em qualquer grande proposta de reformulação da vida humana, encontra condições bastante difíceis para um diálogo efetivo com a experiência contemporânea.

“Tudo no ar parece confirmar a sensação ge-
neralizada de que 'os tempos modernos ago-
ra terminaram' e que alguma divisão, algum
corte fundamental ou salto qualitativo, ago-
ra nos separa decididamente daquele que foi
o novo mundo do início do século XX, o do
modernismo triunfante." (Jameson, apud
Anderson, 1999, p. 60)

As profundas alterações no modo de vida trazidas pela contemporaneidade colocam em 
cheque as proposiçóes artísticas modernas e requisitam aos artistas de teatro novos procedimentos estéticos, em consonância com a percepção e a sensibilidade do espectador dos nossos dias, solicitando a elaboração de propostas artísticas que se posicionem frente ao horizonte de expectativa do receptor contemporâneo, que apresenta feições particulares.

\section{A negação pós-moderna}

Como oposição às utópicas propostas do período anterior e sugerindo um tipo diferente de relação entre a arte e a sociedade, a cultura pósmoderna, a partir das últimas décadas do século XX, expõe a crise de muitas certezas confortáveis, subvertendo, até ironicamente, as altivas verdades do modernismo, do evolucionismo e até mesmo dos modelos críticos. Os pós-modernos, em sua negação ao movimento anterior, relativizam a crítica social e tendem a render-se a uma resignação acomodada, "[...] a um ceticismo politicamente paralisante, a um populismo vistoso, a um relativismo moral bem desenvolvido e a uma marca de sofismo segundo o qual, uma vez que todas as convenções são, de qualquer maneira, arbitrárias, podemos perfeitamente nos adequar às do mundo livre. Ao puxar o tapete das certezas de seus adversários políticos, essa cultura Pós-Moderna freqüentemente se deixou sem chão também, não havendo mais razōes para resistirmos ao fascismo - a não ser a alegação debilmente pragmática de que o fascismo não é o modo como as coisas funcionam em Sussex ou em Sacramento" (Eagleton, 1999, p. 30).

Ao dar a guinada, visando escapar do discurso ideologizante, o pós-modernismo, ou parcela significativa de sua produção, escorrega para a absoluta ineficácia. $\mathrm{O}$ tratamento jocoso a qualquer esboço de vontade crítica faz, por vezes, o sorriso gelar nos lábios.

A arte contemporânea não está, contudo, restrita a estas produções paralisantes, sendo, de fato, empurrada em duas direções: por um lado, uma vontade de rever criticamente as propostas modernistas e reincorporar elementos ao ambiente atual, e, por outro, um ímpeto de "se lançar de cabeça no novo mundo sedutor da fama, do comercialismo e do sensacionalismo" (Wollen, apud Anderson, 1999, p. 124). Estas últimas proposições que, via de regra, ajustam-se ou fazem apelo ao espetacular e estão apoiadas no abastecimento maciço do mercado, têm predomínio absoluto no período.

Todavia, além das tendências pós-modernas que pretendiam instalar um produto cultural de mais fácil acesso, geralmente associado à utilização dos novos media, há também, por parte de produtores culturais, a busca de um além do modernismo, pela radicalização das suas negaçôes da inteligibilidade imediata e da proposição autoral feita ao receptor.

A modernidade inaugurou a participação em todas as instâncias sociais. A arte desse período, imbuída deste espírito, pretendia provocar o espectador, propondo-lhe que raciocinasse criticamente acerca da obra e elaborasse interpretações próprias sobre a mesma. Os artistas modernos promovem, assim, a pluralidade interpretativa, construindo uma obra de arte aberta, elaborada tendo em vista a necessária participação do espectador, instaurando uma forma artística em que o espectador se tornaria co-autor da obra. "A própria recepção das obras se personaliza, torna-se uma experiência estética 'não amarrada' (Kandinsky), polivalente, fluida." (Lipovetsky, 1983, p. 95) A arte contemporânea, por sua vez, em sua tendência de análise e especificação do modernismo, vai levar ao extremo esta proposição de autoria feita ao espectador, de maneira que não só a significação fica ao seu encargo, mas, em certo sentido, a própria 'escritura' artística - o que se traduz por uma radicalização da abertura da forma e da significação.

A estética da destruição-construção do moderno - e a desconstrução da cena apresentada pelo teatro épico brechtiano, com a interdependência dos elementos, é um bom exemplo disto - deixa a obra aberta para que o espectador elabore outras construções, outras 
montagens possíveis. O teatro precisava apresentar um mundo passível de transformação e, como o mundo, a obra teatral poderia ser construída de outras maneiras pelo espectador. A experiência artística contemporânea vai levar ao extremo esta idéia, apresentando não mais uma obra aberta, mas uma obra explodida. A realidade não se mostra mais desconstruída, transformável, e sim dessubstancializada, uma realidade que precisa ser concebida. $\mathrm{Ou}$ seja, não há mais uma realidade, esta não é mais facilmente apreendida, portanto, não há uma obra, mas possíveis obras a serem concebidas pelo receptor. Assim, a elaboração da obra teatral efetuada pelo espectador vai estar necessariamente vinculada à sua construção de realidade.

A arte na contemporaneidade, deste modo, tenta resolver o impasse gerado pela impossibilidade de conceber um todo orgânico, uma narrativa que abarque a totalidade, propondo não uma síntese aberta à conclusão e, sim, recortes que proponham uma atitude analítica ao espectador. Não mais a busca de construir um consenso acerca da leitura do mundo, mas algo que possa ser contemplado e analisado a partir do ponto de vista próprio do espectador. Ou seja, não se está propondo ao espectador uma reflexão conclusiva, a partir de uma síntese, mas uma reflexão analítica, a ser elaborada por ele a partir de uma disjunção estética apresentada. O artista trabalha recortando e definindo as frações de vida sobre as quais irá se debruçar, mas os pedaços recortados não formam necessariamente um todo orgânico. Em oposição aos projetos modernos, a contemporaneidade implementa uma guerra contra as totalidades, pois a relatividade ganhou o cotidiano e os pontos de vista possíveis estão multiplicados.

Se a noção de totalidade associada à construção do novo está prejudicada, os artistas contemporâneos retratam em suas obras não mais uma harmonia orgânica, como aquela da arte moderna, em que as partes formavam um todo, por mais que cada fragmento pudesse ser radicalmente diferente do outro. A arte recente se constitui, diferentemente, de um hibridismo desconexo, calcado na justaposição de elementos que não se harmonizam, ou então de partes que soam desnecessárias ao todo funcional da obra - o que contraria a noção de organicidade observada no período anterior ou, ao menos, pressiona esta noção para além dos seus limites.

A disjunção das partes, a multiplicidade de estilos que definem uma descontinuidade lingüística, propõem, por sua vez, uma atitude criativa ao interlocutor. Porém, não mais como sugeria a arte moderna, enquanto obra aberta que espera uma conclusão, obra interrogativa que espera uma resposta. A arte contemporânea formula, neste sentido, uma releitura da arte moderna, radicalizando suas propostas. Não se trata mais de uma obra desconstruída, pronta para ser remontada, e sim de uma obra explodida, que provoca o receptor a concebê-la. Se a arte moderna propõe uma elaboração conclusiva, a arte da contemporaneidade propõe leituras plurais, dissensuais. A compreensão formulada pelo espectador vai estar mais extremadamente vinculada às leituras singularizadas de mundo, já que não há uma visão de mundo consensual proposta na obra.

A falta de condições para o "novo", já que tudo foi dito e experimentado, lança-nos numa atitude analítica em direção ao passado, ao contrário da modernidade que apontava para um futuro utópico. Mas "o recurso à historiografia se dá como instrumento de alteração do passado, não como sua reconstrução e preservação" (Teixeira Coelho, 1995, p. 94). Sem encontrar condiçôes que permitam vislumbrar novos caminhos, a contemporaneidade está investida em um movimento de análise da história. Este diálogo aberto com o passado pode ser percebido nas diversas formas de arte que utilizam elementos de todas as épocas, mesclando variados estilos.

A multiplicidade de estilos ajuntados se dá assumidamente, deixando-os evidenciados, sem a preocupação de criar uma unidade entre eles, de torná-los orgânicos, integrados, apresentando-os como diferentes textos, diferentes narrativas desencontradas, decompostas. Procurase, assim, manter a tensão entre os variados 
pedaços. O que antes era compreendido por unicidade agora o é por diferenciação; ao invés de relacionar a parte, o fragmento, com o todo, o espectador relaciona as partes entre si, pedaços que não se encaixam e não compõem necessariamente uma totalidade.

Ao espectador contemporâneo é proposto, assim, que se movimente pelos vários fragmentos de uma não-obra, pedaços que, mesmo em sua soma, não constituem um todo. Lançado numa seqüência de recortes, de pedaços decompostos - que se diferenciam da seqüência das cenas épicas modernas, que pertenciam a uma mesma narrativa e que eram desconstruídas como partes de um todo -, o espectador desloca-se de uma narrativa para outra. Cada narrativa suscita a "renarrativização" das anteriores, estabelecendo uma tensão entre as diversas narrativas. Um pedaço redimensiona, recontextualiza o outro. Cada retorno reflexivo não possibilita uma visão do todo, a elaboração de uma síntese, mas uma visão sempre parcial de quem analisa pedaços que não estruturam uma totalidade.

Soma-se à superposição de narrativas o ajuntamento de estilos diversos, um entrecruzamento de textos e estilos que se sucedem aos golpes e que não se ligam necessariamente por relações causais ou por evidências fatuais, mas por livre associação ou por uma relação de necessidades, desejos, vontades, etc. Uma seqüência de pedaços que redimensiona o sentido de cada um deles isoladamente. Estes fragmentos narrativos não se juntam tampouco como colagem aleatória e constituem uma proposição que só se justifica enquanto revisão dos procedimentos estéticos da modernidade. Ou seja, a explosão das narrativas e a tensão estabelecida entre os fragmentos narrativos vão radicalizar o desmembramento de uma narrativa em várias partes, levando ao extremo o procedimento proposto pelo teatro épico brechtiano:

“ [...] uma tensão que é nota dominante entre todas as partes distintas de que se compõe e que as 'carrega' reciprocamente. Esta forma é, assim, tudo, menos um conjunto de fatos simplesmente alinhados em seqüência." (Brecht, 1978, p. 29)

Esta característica da produção artística contemporânea, marcada pela multiplicidade e pela heterogeneidade, que se apresenta como proposição radical de autoria ao espectador, pode ser compreendida como a suposta existência de uma obra ausente, que será escrita pelo receptor, um evento inexistente que será criado pelo contemplador. Um exemplo explícito e extremado desta proposição criativa pode ser observado no poema China, transcrito abaixo:

Moramos no terceiro mundo a contar do sol. Número três. Ninguém nos diz o que fazer.

As pessoas que nos ensinaram a contar estavam sendo muito boazinhas.

Sempre é hora de ir embora.

Se chover, você ou tem ou não tem um guarda-chuva.

O vento faz voar o seu chapéu.

O sol também se levanta.

Preferia que as estrelas não nos descrevessem uns aos outros, gostaria que nós mesmos o fizéssemos.

Corra na frente de sua sombra.

Uma irmã que aponta para o céu pelo menos uma vez a cada década é uma boa irmã.

A paisagem é motorizada.

O trem leva você para onde ele for.

Pontes no meio da água.

Pessoas desgarradas em grandes vias de concreto, indo para o avião.

Não se esqueça de como vão parecer seu sapato e seu chapéu quando você tiver desaparecido.

Até as palavras flutuando no ar fazem sombras azuis.

Se o gosto for bom, nós comemos.

As folhas estão caindo. Chame a atenção

para as coisas.

Escolha as coisas certas.

$O i$, adivinhe o que aconteceu? O quê? Apren- 
di a falar. Fantástico.

A pessoa cuja cabeça estava incompleta começou a chorar.

Enquanto caía, o que a boneca podia fazer? Nada.

Vá dormir.

Você fica superbem de shorts. E a bandeira parece estar muito bem também.

Todos se divertiram com as explosôes.

Hora de acordar.

Mas é melhor nos acostumarmos com os sonhos.

(Perelman, apud Jameson, 1996, p. 55)

Este poema, conta-nos Jameson, e aqui estaria a sua relevância, foi concebido pelo autor a partir de um livro de fotos sobre a China, comprado em uma papelaria no bairro de Chinatown, em Nova York. Para cada foto, o autor criou uma legenda, o poema é o ajuntamento destas legendas. $\mathrm{O}$ sentido primeiro das frases está vinculado a este livro ausente, a estas imagens fotográficas que estão fora do alcance do leitor do poema. Ao leitor cabe preencher este vazio criado pela retirada das fotos. O leitor pode, quem sabe, criar um outro livro, de fotos imaginárias, um outro sentido possível para estas narrativas desencontradas, uma outra obra. À profusão de narrativas, segue-se uma profusão de silêncios que se interpõem entre uma frase e outra - ou o leitor se aventura por este vácuo que se estabelece ou pode simplesmente se retirar sem qualquer iniciativa autoral, criadora. O poema, como é característica da arte recente, não tem moral e nem aponta conclusões, apenas põe na bandeja opçóes para o self-service analítico oferecido aos leitores, cabendo ao receptor desvendar um possível banquete oculto.

\section{A proposição pedagógica da arte contemporânea}

O caráter estético, reflexivo, do fato artístico está diretamente relacionado com a sua proposição dialógica, com a efetiva participação do receptor enquanto co-criador do evento, e aqui está inscrito o caráter educacional da experiência artística. Qualquer análise do aspecto pedagógico do teatro, portanto, não pode estar desvinculada da própria busca do sentido desta arte, da sua capacidade de dar conta da experiência de seu tempo, tendo em vista, como foi dito, que a sua possibilidade pedagógica inscreve-se em sua própria viabilidade estética.

Uma das importantes características do teatro moderno foi o estímulo à participação do espectador, convidando-o a estabelecer uma relação co-autoral com o espetáculo, especialmente em uma atitude responsiva, de quem formula interpretações para as questôes apresentadas pelo autor. A arte teatral contemporânea, por sua vez, pretende levar ao extremo esta atitude proposta ao contemplador.

O teatro épico brechtiano funcionava como um modelo científico exposto ao espectador, apresentado em diálogo aberto com a platéia, convidando-a a refletir sobre aquele sistema, que funcionava como uma tradução sintética da vida social. Um modelo desmontado que era (re)montado na frente do espectador, revelando todos os seus mecanismos, os seus meandros, já que estava inserido na lógica estética da construção-desconstrução que inspirava a arte moderna. Nas últimas décadas, nenhuma narrativa se acha em condições de sintetizar a vida social contemporânea, pela falta de visão de conjunto, pela impossibilidade de abranger os múltiplos pontos de vista possíveis, as múltiplas interrogações. As grandes narrativas estão explodidas em elementos de linguagem, com os quais cada qual elabora combinações nem sempre estáveis, ou seja, a dita "falência" dos projetos de renovação leva a uma decomposição, a um sucateamento destes projetos, produzindo vários elementos de linguagem, fragmentos de linguagem narrativa que advêm desta pulverização e que se prestam a explicações localizadas e não mais globais. No teatro contemporâneo, em sua tendência de análise e redimensionamento do épico moderno, cada espectador trabalha com estes e outros elementos 
de linguagem a seu modo, formulando uma concepção própria para o evento.

O teatro recente não se encontra mais em condições de apoiar-se na proposição concreta de um movimento coletivo, sustentado por uma grande narrativa, na proposta de engajamento em um projeto político-social, fundamentandose, portanto, na provocação aos espectadores, formulando um raciocínio estético em que caberia ao espectador a elaboração das questôes que lhe pareçam pertinentes, a partir da sua concepção do evento, da sua leitura de mundo.

A vontade educacional encontrada em tendências da arte moderna efetivava-se, assim, na instauração de uma atitude participativa, no convite ao receptor para exercer a autoria que lhe cabe, para elaborar uma compreensão própria do evento. Nesta proposição reflexiva estava estruturado o caráter pedagógico do teatro épico, disposto a sacudir o espectador refestelado na poltrona e abandonado à corrente da narrativa que lhe era apresentada. O teatro brechtiano propunha-se, assim, a potencializar o caráter pedagógico da atividade artística, "cientificizando" a criação teatral, potencializando o seu caráter estético, a reflexividade da obra. A dinamização da recepção, contudo, precisa estar sempre vinculada a padróes estéticos contemporâneos. Esta atitude reflexiva proposta ao espectador pode também ser percebida na arte recente, que mantém, não sem transformála, esta vontade pedagógica presente na arte moderna. As recentes transformações na recepção alteram os procedimentos artísticos, mas não suprimem a reflexividade. A proposição participativa e, neste sentido, pedagógica, é não apenas conservada, mas radicalizada.

"A característica talvez mais importante de toda a arte recente, mas que já era fundamental na arte de vanguarda, é a reflexividade. A obra não só reflete sobre si mesma - é auto-referente, metalingüística, em termos semióticos-, mas é reflexiva porque o prazer e a significação que dela derivam só podem ser encontrados na reflexão." (Favaretto, 1997, p. 29)
Ao invés de propor que o espectador feche a obra que se apresenta aberta, com uma elaboração responsiva, definindo um significado para os signos propostos, o teatro contemporâneo pretende que a platéia participe acrescentando significantes ao jogo de linguagem apresentado. Menos interessada em formular uma compreensão, um fechamento, uma sintetização da obra, em criar uma unidade para as partes, a arte da contemporaneidade quer propor ao espectador que teça análises, que elabore outros significantes, empreendendo, assim, uma atitude mais extremadamente autoral. O artista está menos preocupado com o entendimento que a obra suscita no espectador do que com a provocação que lhe faz.

A reflexividade suscitada pelo teatro recente se depara com condiçôes específicas, que requerem propostas estéticas que estejam em consonância com as alteraçôes no modo de vida contemporâneo. A arte teatral dialoga, atualmente, com um indivíduo bem informado, participante incondicional da hiper-ramificada rede de comunicação. Porém, se a espetacularidade do cotidiano promovida pelos media, associada aos múltiplos informes, proporciona um amplo conhecimento acerca dos fatos sociais, "a informação excessiva, afirma-se, é uma das melhores induçôes ao esquecimento" (Harvey, 1992, p. 315). E isto porque na superdosagem informativa não há espaço e tempo para a reflexão: com a mesma velocidade que entra na rede, a notícia desaparece, qualquer história veiculada é rapidamente relegada ao caráter de passado distante, sem ser ao menos digerida. Os indivíduos se vêem, assim, sedados por uma overdose de informação. Observadores "conscientizados" mas desmobilizados; em lugar de uma passividade alienada, uma apatia bem informada.

Talvez se possa conceber que o teatro contemporâneo pretenda suscitar neste espectador habituado a fragmentos narrativos descontínuos a formulação de contra-lances inesperados, provocando-o a elaborar leituras próprias, surpreendentes, estimulando-o a fazer jogadas inventivas. $\mathrm{O}$ caráter pedagógico do teatro de espetáculo deixaria, 
desta maneira, de ter um valor formador para ter um valor performático.

$\mathrm{O}$ conceito de performance, aqui aplicado, não tem o sentido atribuído ao melhoramento da capacidade competitiva, de gerar lucros, a valor de mercado, mas, sim, à capacidade de desferir golpes, de produzir elaborações estéticas próprias, inesperadas. A idéia de formar espectadores, que pressupóe um patamar a ser atingido, seria substituída pela idéia de processo, de provocação dialógica. Um teatro interessado tanto na capacidade performática do espectador, de reagir aos lances propostos, de desferir golpes surpreendentes, quanto na performance da própria atividade artística, em sua capacidade provocativa, de formular novos lances, novos jogos de linguagem.
"Ela [a melhor performatividade] resulta de um novo arranjo dos dados, que constituem propriamente um 'lance'. Este novo arranjo obtém-se, a maioria das vezes, pondo em conexão séries de dados tidos até então como independentes. Pode-se chamar imaginação a esta capacidade de articular juntamente o que não estava. A velocidade é uma propriedade da imaginação." (Lyotard, 1989, p. 106)

O teatro recente, assim, calcado no estímulo à reflexividade, provocaria esta capacidade inventiva, ativando uma melhor performatividade, estimulando a “imaginação', que permite ou realizar um novo lance, ou mudar as regras do jogo" (Lyotard, 1989, p. 106).

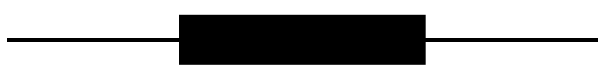

Referências bibliográficas

ANDERSON, Perry. As origens da Pós-Modernidade. Rio de Janeiro: Zahar, 1999.

BRECHT, Bertolt. Estudos sobre Teatro. Rio de Janeiro: Nova Fronteira, 1978.

EAGLETON, Terry. As Ilusões do Pós-Modernismo. Rio de Janeiro: Zahar, 1998.

FAVARETTO, Celso F. Estética na era tecnológica. Atrator Estranho, São Paulo, n. 27, mar. 1997.

JAMESON, Fredric. Pós-Modernismo: a lógica cultural do capitalismo tardio. São Paulo: Ática, 1996.

LIPOVETSKY, Gilles. A Era do vazio: ensaio sobre o individualismo contemporâneo. Lisboa: Relógio D’Água, 1983.

LYOTARD, Jean-François. A condição pós-moderna. Lisboa: Gradiva, 1989.

TEIXEIRA COELHO, J. Moderno Pós Moderno. São Paulo: Iluminuras, 1995.

TOURAINE, Alain. Crítica da Modernidade. Petrópolis: Vozes, 1997. 